DOI https://doi.org/10.30525/978-9934-26-109-1-30

\title{
ОСНОВИ СИСТЕМНОГО ПІДХОДУ ДО ВИРІШЕННЯ ЗАДАЧ ПІДВИЩЕННЯ ЕФЕКТИВНОСТІ МІЖНАРОДНИХ ВАНТАЖНИХ ПЕРЕВЕЗЕНЬ
}

\author{
Чупайленко О. А. \\ кандидат технічних наук, дочент, \\ доцент кафедри міжнародних перевезень та митного контролю \\ Національний транспортний університет \\ Білокур М. В. \\ аспірант кафедри міжнародних перевезень та митного контролю \\ Національний транспортний університет \\ Поліщук Р. В. \\ аспірант кафедри міжнародних перевезень та митного контролю \\ Національний транспортний університет \\ м. Київ, Украӥна
}

За останні 6 років забезпечення реалізації транзитного потенціалу України суттєво зросла роль міжнародних автомобільних перевізників (приватні підприємства, об’єднані Асоціацією міжнародних автомобільних перевізників України). Якщо в період 32014 по 2020 роки транзитні вантажопотоки територією України трубопровідним та залізничним видами транспорту суттєво скоротились (відповідно - на 44\%), то транзитні автомобільні перевезення вантажів територію України зросли в 3,6 раз [1, с.448].

До запровадження нових, більш жорстких норм i стандартів Україна підготовлена на недостатньому рівні: система організації міжнародних вантажних перевезень, автомобільним транспортом $\epsilon$ недосконалою, а в забезпеченні функціонування автомобільного транспорту відсутній системний підхід; рухомий склад парку автомобільного транспорту є технічно застарілим, а його оновлення відбувається повільними; рівень безпеки перевезень низький, значно гірші в порівнянні 3 країнами $Є С$ показники аварійності на автомобільному транспорті (за показником смертності від ДТП наша країна посідає п'яте місце у Свропі) [1, с. 449]; експлуатаційні характеристики вітчизняної транспортної інфраструктури не 
дозволяють забезпечити виконання «Європейської угоди щодо роботи екіпажів транспортних засобів, які виконують міжнародні автомобільні перевезення (СУТР)» (практично відсутні відповідним чином обладнані місця для стоянок та відпочинку водіїв).

До 2022 року мають бути запроваджені більш жорсткіші норми і стандарти стосовно функціонування внутрішнього і міжнародного ринку транспортних послуг та умов доступу до нього. В значній мірі вони будуть визначати подальший розвитку та формування транспортного простору як центральноєвропейських країн, так і країн Східної та Південно-Східної Свропи, Кавказу та Середньої Азії. За оцінками експертів, нові норми і стандарти можуть суттєво змінити конфігурацію вантажних перевезень. А в разі відсутності адекватної державної відповіді з боку України на зовнішні виклики - суттєво витіснити українських (зокрема автомобільних) перевізників 3 міжнародного ринку транспортних послуг.

Більш жорсткіші норми і стандарти стосовно функціонування внутрішнього і міжнародного ринку транспортних послуг та умов доступу до нього будуть охоплювати всі види внутрішнього транспорту (автомобільний, трубопровідний, залізничний i внутрішній водний транспорт і змішані перевезення) та будуть направлені на спрощення прикордонних процедур, забезпечення безпеки руху та перевезень небезпечних вантажів, підвищення екологічності та енергоефективності транспорту, функціонування транспортної інфраструктури тощо.

Таким чином, враховуючи вищенаведене, можна сказати, що відсутність державної підтримки та скорочення присутності українських транспортних організацій може спричинити істотне скорочення валового внутрішнього продукту та ролі України, як впливового гравця на внутрішньому і міжнародному ринку транспортних послуг.

Що стосується технології міжнародних вантажних перевезень, слід відзначити, що ринкові відносини пред’являють до транспорту жорсткі вимоги щодо прискорення часу доставки вантажів при мінімізації витрат на транспортування. Між виробником та споживачем створюється складна система транспортних взаємин, яка повинна забезпечити високий рівень якості транспортного обслуговування.

При будь-якому із зазначених способів вантажних перевезень, технологія процесу їх доставки автомобільним, залізничним, водним, авіаційним транспортом чи їх різними комбінаціями, включаючи навантажувально-розвантажувальні, митні та інші операції, спрямована на зменшення часу слідування вантажу. На сьогоднішній день система процесу змішаних перевезень, являє собою доставку спочатку 
на судні з подальшим розвантаженням на площадку порту і навантаженням на вантажний автомобіль або платформу для продовження переміщення вантажу до митниці (де відбувається огляд та оформлення), а після чого передача вантажоодержувачу.

Створення єдиної міжнародної транспортно-логістичної системи, географічне положення транспортного простору України, а також наявність багатьох транспортних коридорів вимагає наступне [2, с. 66]: окремого аналізу управління роботою транспортних вузлів; забезпечення координації та взаємодії усіх видів транспорту; впровадження сучасних досягнень науково-технічної революції в роботу транспорту.

Розробка ефективної організації доставки вантажів 3 взаємоузгодженістю всіх ланок транспортного процесу викликала необхідність великої кількості теоретичних і експериментальних досліджень з різних питань транспорту. За функціональними ознаками ix можливо класифікувати за такими напрямками: загальні питання теорії транспортних систем і процесів; експлуатаційні властивості транспортних засобів; взаємодія видів транспорту і транспортноекспедиційна діяльність; формування логістичних систем.

Аналіз наукових праць [2, с. 67; 3, с. 264] дозволив зробити наступні висновки, що: одними з основних факторів, що впливають на ефективність функціонування ТС, є якість маршрутизації вантажних перевезень і рівень взаємодії різних видів транспорту; для отримання адекватних результатів при моделюванні окремих компонентів ТС необхідно враховувати їх стохастичні характеристики; оцінка виконання міжнародних вантажних перевезень в ринкових умовах потребує удосконалення відповідних критеріїв ефективності.

Системна мета $\mathrm{M}_{\mathrm{c}}$ може бути розподілена шляхом декомпозиції на локальні цілі $\mathrm{M}_{\mathrm{ik}}$, які враховують окремі аспекти транспортної діяльності. Звідси, задачі дослідження ставляться і вирішуються комплексно з урахуванням функціональних взаємозв'язків згідно 3 формулою системного аналізу:

$$
\begin{aligned}
& \mathrm{M}_{\mathrm{c}} \rightarrow \mathrm{M}_{\mathrm{i \kappa}}\left\{\tilde{\mathrm{M}}_{\mathrm{i \kappa}}: \tilde{\mathrm{M}}_{\mathrm{i \kappa}} \in \mathrm{M}_{\mathrm{i \kappa}} ; \mathrm{i}=1,2 \ldots \mathrm{I}, \mathrm{K}=1,2, \ldots \mathrm{K}\right\} \text {, } \\
& \mathrm{M}_{\text {ік }} \rightarrow \mathrm{F}_{\text {ік }} \quad\left\{\tilde{\mathrm{F}}_{\text {ік }}: \widetilde{\mathrm{F}}_{\text {ік }} \in \mathrm{F}_{\text {ік }} ; \mathrm{i}=1,2 \ldots \mathrm{I}, \mathrm{K}=1,2, \ldots \mathrm{K}\right\} \text {, } \\
& \mathrm{F}_{\text {ік }} \rightarrow 3_{\text {ік }} \quad\left\{\widetilde{3}_{\text {ік }}: \widetilde{3}_{\text {ік }} \in 3_{\text {ік }} ; \mathrm{i}=1,2 \ldots \mathrm{I}, \mathrm{\kappa}=1,2, \ldots \mathrm{K}\right\}, \\
& 3_{\text {ік }} \rightarrow \mathrm{R}_{\text {ік }} \quad\left\{\widetilde{\mathrm{R}}_{\mathrm{i \kappa}}: \widetilde{\mathrm{R}}_{\text {ік }} \in \mathrm{R}_{\text {ік }} ; \mathrm{i}=1,2 \ldots \mathrm{I}, \mathrm{K}=1,2, \ldots \mathrm{K}\right\} \text {, }
\end{aligned}
$$




$$
\begin{aligned}
& \mathrm{R}_{\mathrm{i \kappa}} \rightarrow \mathrm{A}_{\mathrm{i \kappa}}\left\{\tilde{\mathrm{A}}_{\mathrm{i \kappa}}: \tilde{\mathrm{A}}_{\mathrm{i \kappa}} \in \mathrm{A}_{\mathrm{i \kappa}} ; \mathrm{i}=1,2 \ldots \mathrm{I}, \mathrm{K}=1,2, \ldots \mathrm{K}\right\}, \\
& \mathrm{A}_{\mathrm{i \kappa}} \rightarrow \Pi_{\text {ік }}\left\{\widetilde{\Pi}_{\mathrm{i \kappa}}: \widetilde{\Pi}_{\mathrm{i \kappa}} \in \Pi_{\mathrm{i \kappa}} ; \mathrm{i}=1,2 \ldots \mathrm{I}, \mathrm{\kappa}=1,2, \ldots \mathrm{K}\right\}, \\
& \Pi_{\text {iк }} \rightarrow \Sigma_{\text {ік }} \quad\left\{\widetilde{\Sigma}_{\text {iк }}: \widetilde{\Sigma}_{\text {iк }} \in \Sigma_{\text {iк }} ; \mathrm{i}=1,2 \ldots \mathrm{I}, \mathrm{K}=1,2, \ldots \mathrm{K}\right\} \text {, } \\
& \Sigma_{\text {ік }} \rightarrow \mathrm{P}_{\text {ік }} \quad\left\{\widetilde{\mathrm{P}}_{\text {ік }}: \widetilde{\mathrm{P}}_{\text {ік }} \in \mathrm{P}_{\text {ік }} ; \mathrm{i}=1,2 \ldots \mathrm{I}, \mathrm{K}=1,2, \ldots \mathrm{K}\right\},
\end{aligned}
$$

де $\mathrm{M}_{\mathrm{c}}, \mathrm{M}_{\mathrm{i \kappa}}$ - відповідно системна і локальна мета забезпечення результативності вдосконалення транспортного процесу;

$\mathrm{F}_{\text {iк }}$ - множина функцій, які необхідно реалізувати на i-му проміжку часу;

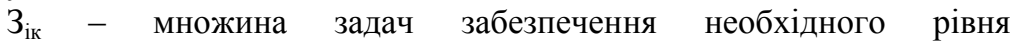
результативності вдосконалення;

$\mathrm{R}_{\mathrm{i \kappa}}$ - множина методів вирішення задач;

$\mathrm{A}_{\text {iк }}$ - множина алгоритмів вирішення задач $3_{\text {iк }}$;

$\Pi_{\text {iк }}$ - програмно-інструментальні засоби вирішення задач $3_{\text {ік }}$;

$\Sigma_{\text {iк }}$ - множина систем (підсистем), що реалізує множину задач $3_{\text {iк }}$ на даному проміжку часу;

$\mathrm{P}_{\text {iк }}-$ результати вирішення множини задач $3_{\text {iк }}$ на даному проміжку часу;

к - номер компоненти.

Використовуючи системний підхід можна вирішити задачу підвищення ефективності міжнародних вантажних перевезень за рахунок раціональної маршрутизації перевезень з системною метою $\mathrm{M}_{\mathrm{c}}$ якісного та ефективного вдосконалення транспортного процесу.

\section{Література:}

1. Ширясва С.В. Фактори, що впливають на формування i розвиток мультимодальної транспортної системи України в сучасних умовах. Вісник Національного транспортного університету. Серія «Технічні науки». 2020. Вип. 1 (46). С. 446-454.

2. Прокудін Г.С., Чупайленко О.А., Пилипенко Ю.В. Оптимізація мультимодальних вантажних перевезень маршрутами міжнародних транспортних коридорів. Вісник Східноукраӥнського Національного університету імені Володимира Даля. 2019. Вип. № 2 (250). С. 65-73.

3. Prokudin G.S., Chupaylenko O.A., Dudnik O.S. Methods for Determining Optimal Characteristics of Transportation Networks. Вісник Національного транспортного університету. Серія «Технічні науки». Вип. № 1 (40). 2018. С. 262-273. 